Review Article

\title{
Transmission Specificity and Coinfection of Mastrevirus with Begomovirus
}

\author{
Sana Khalid ${ }^{1,2 *}$, M. Zia-ur-Rehman ${ }^{1}$, Usman Hameed ${ }^{1,3}$, Farah Saeed ${ }^{1}$, Farah Khan ${ }^{2}$ and Muhammad Saleem Haider ${ }^{1}$ \\ ${ }^{1}$ Institute of Agricultural Sciences, University of the Punjab, Lahore, Pakistan \\ ${ }^{2}$ Department of Botany, Lahore College for Women University, Lahore, Pakistan \\ ${ }^{3}$ Government Murray College, Sialkot, Pakistan \\ *For correspondence: sanakhalid4@yahoo.com
}

\begin{abstract}
Coat protein $(\mathrm{CP})$ of geminivirus is not requisite for replication of viral DNA yet it is multifunctional and have crucial role in virus transmission by insect vector, systemic infection and virion development. Although in geminivirus, systemic infection rely both on function of $\mathrm{CP}$ and specific host-geminivirus-vector interaction but in bipartite begomoviruses $\mathrm{CP}$ is dispensable for systemic infection and progression of symptoms. Nevertheless its role in spreading systemic infection cannot be neglected in monopartite viruses' viz. mastrevirus, begomoviruses and curtoviruses, therefore any alteration in CP gene upshot in a new epidemiological adaptation hence worth to study. So the study was designed to present a better picture to view regarding coinfection within different Geminiviruses belonging to mastrevirus and begomovirus particularly due to vector inspecificity consequently resulted in revolutionary recombination events, which ultimately yield new viruses, have more drastic affects on crops. Moreover, co-evolution of both genera may open new horizons in understanding the complexity of cotton leaf curl disease and then to chalk out strategies to counter this emerging threat in Pakistan. (C) 2017 Friends Science Publishers
\end{abstract}

Keywords: Geminiviruses; Transmission; Insect specificity; Coinfection

\section{Introduction}

Viruses always have sound effect on the growth of plants, besides interacts with host defence mechanism, leads to the alteration of crop physiology. Agricultural production, around the globe has been continuously affected due to diseases spread by geminiviruses (Inouye and Osaki, 1980). Previously knowledge about the viral pathogens of diseases was restricted before the isolation, structure and morphology of virus particles linked with such diseases like maize streak and beet curly top (Bock et al., 1974; Mumford, 1974). Cotton leaf curl disease (CLCuD) now become the subject of massive concern globally including Pakistan (Briddon and Markham, 2001; Mansoor et al., 2003; Amin et al., 2006). Intergenic recombinations due to coinfection of two different gemniviruses belonging to dissimilar genera have been reported to play major role in establishment of current taxonomic composition of the family Geminiviridae e.g., dicot-infecting mastreviruses are specifically prone to trans-encapsidation. Yet coat protein (CP) has a common role for all the members of family geminiviridae; determinant of vector specificity because it is essential for insect transmission. THIS review broadens our knowledge about the diversity and distribution of mastreviruses across Pakistan and will provide the necessary information regarding their control.

\section{Cotton Leaf Curl Disease (CLCuD) in Historical Perspective}

Gossypium virus-1 has been reported as causative viral agent for Cotton leaf curl and first report was documented in Nigeria infecting Gossypium barbadense L. (Farquharson, 1912). Later on, it was investigated that whitefly is a biotic agent in dispersal of this disease, after twelve years in Sudan (Jones and Mason; 1926; Bailey, 1934). Moreover, in 1960s long staple cotton production was significantly affected due to Cotton Leaf Curl Disease (CLCuD) both in Tanzania and Gezira whilst, in western part of India $G$. hirsutum was severely attacked by geminiviruses causing this disease (Singh et al., 1996). Geminiviruses (genus Begomovirus; family Geminiviridae), also spread across northwestern India and Pakistan caused drastic reduction in cotton production and was reported to be caused by whitefly (Bemisia tabaci Gennadius) as one and only biotic constraint to all the cotton plants (Ahmad et al., 2011). Abnormal and unusual symptoms of CLCuD were noticed on infected plants with reference plants like swelling of veins, downward or upward curling/cupping of leaves, enation formation on the lower surface of 
leaves mainly midrib and leaves were greener than usual (Farooq et al., 2011). These symptoms, however, are changeable with age of the plant at the time of infection and variety of cotton.

\section{Geminiviruses}

Recent research reports depict that Geminiviruses possess single stranded DNA (ssDNA) molecules ( 2500 to $\sim 3100$ nucleotides) encapsidated in twinned icosahedral capsid, with circular monopartite or bipartite genomes but can encode only few genes and its replication mostly depend on host plant replication machinery. Furthermore, they are broadly disseminated viruses infecting both monocots (e.g. maize and wheat) and dicots like tomato and cassava (Hanley-Bowdoin et al., 1999; 2004). Further geminiviruses has been divided into seven genera namely Begomovirus, Curtovirus, Mastrevirus, Topocuvirus, Eragrovirus, Turncurtovirus and Becurtovirus warp and woof on their (i) genome organization (ii) insect vector (iii) biological properties and (iv) host range (Varsani et al., 2014) as depicted clearly in Table1. Whitefly (Bemisia tabaci Gennadius) has been reported as insect vector for the genus begomoviruses in contrast to Mastreviruses, which has been reported to transmit by leafhoppers (Orosius albicinctus Distant) to a range of host plants.

Begomoviruses cause a lot of economic losses and listed as largest genus of geminiviruses (133 known monopartite begomoviruses originating from the Old World - OW). Their genome consists of two components, one is called DNA-A and the other is DNA-B, both are $\sim 2.7 \mathrm{~kb}$ in size (Lazarowitz, 1992). Both DNA-A and DNA-B perform different vital roles like viral DNA replication, encapsidation and transcription by DNA-A, while two movement proteins $(\mathrm{BV} 1$ and $\mathrm{BC} 1)$ for translocation of virus by DNA-B (Levy and Tzfira, 2010). New world viruses related to the central and southern American strains such as Tomato leaf deformation virus is a new world virus. However, in the Old World (OW; including Africa, Europe, Australia, Japan, India, Pakistan and other Asian clades) just like bipartite begomoviruses are small in number, mostly have single genomic component similar to DNA-A of bipartite begomoviruses. Monopartite geminiviruses infecting monocots and dicots, with satellites in the Old World (OW), to strict bipartite geminiviruses infecting dicots without satellites in the New World (NW) (Nawazul-Rehman and Fauquet, 2009). Data presented in Table 2 shows that some of viruses are truly monopartite (having only DNA-A) responsible for disease in host plant e.g., Tomato yellow leaf curl Sardinia virus (TYLCSV) (KheyrPour et al., 1991).

\section{Mastreviruses}

Mastreviruses are monopartite, ssDNA viruses with $\sim 2.5-$ $2.7 \mathrm{~kb}$ circular genomes, encapsidated in twinned isometric viral particles but their genomes reported to express four proteins, encoded on the virion and complementary strand equally (Boulton, 2002). The virion strand encoded (1) movement protein $(\mathrm{Mp})$ in plant, vital for cell-to-cell movement in and (2) coat protein (CP) necessary for systemic infection, encapsidation and for transmission of the insect. Cell to cell movement in plants along with vector specificity depends on structural proteins (Liu et al., 1998; 1999; Boulton, 2002). While complementary strand has been reported to encode two replication associated proteins (instead of one, as in other geminiviruses), (1) RepA in trans-activation of late (virion-sense) genes as well as reported to establish a cellular environment conducive for virus replication and (2) RepB, which may be translated from alternatively spliced sense transcripts and required for replication, initiating and terminating rolling circle DNA replication and for the interference of the cell cycle. RepA and RepB shared $\sim 70 \%$ amino acid sequence homology with each other (Schalk et al., 1989; Heyraud-Nitschke et al., 1995; Wright et al., 1997; Hanley-Bowdoin et al., 2004; Ruschhaupt et al., 2013). Further compactness of mastrevirus genomes is highlighted due to its multiple known proteins and their functions, with the exception of MP. Anyhow rate of mastrevirus nucleotide substitution has been found relatively low as compared to basal mutation rates, hence mutation being less deleterious and therefore subject to negative selection (Jeske, 2009). A detailed comparison of protein functions between begomovirus and mastrevirus are depicted in Table2.

\section{Mastrevirus Vector - Orosius albicinctus Distant}

Considerable research efforts have been made which depict that Mastreviruses, occurs across the old world, do not replicate inside their insect vector and are transmitted in a persistant circulative and non-propagative manner (Boulton and Markham, 1986; Harrison et al., 2002). Research reveals that $O$. albicinctus Distant (thought to be similar to Orosius orientalis Matsumura); leafhopper vector of plant viruses and phytoplasmas, successfully transmitted the Chickpea chlorotic dwarf virus (CpCDV). However, $O$. orientalis Matsumura has also been reported to transmit CpCDV to plant species of different families (like Fabaceae, Solanaceae, Chenopodiaceae) and induced CpCDV like symptoms (Horn et al., 1996; Kumari et al., 2004; Farzadfar et al., 2008; Akhtar et al., 2011). Nonetheless, Horn et al. (1993) reported first time the identification of $\mathrm{CpCDV}$ along with many reports from other countries like, Australia, Africa, Europe, the Middle East, Asia, and Far East, Arabian Peninsula and the Indian subcontinent (Horn et al., 1993; Makkouk et al., 1995, 1998; El-Muadhidi et al., 2001; Farzadfar et al., 2002; Makkouk et al., 2003a,b; Kumari et al., 2004; Nahid et al., 2008; Thomas et al., 2010; Muhire et al., 2013; Akhtar et al., 2014). 
Table 1: Description of seven genera of Geminiviruses.

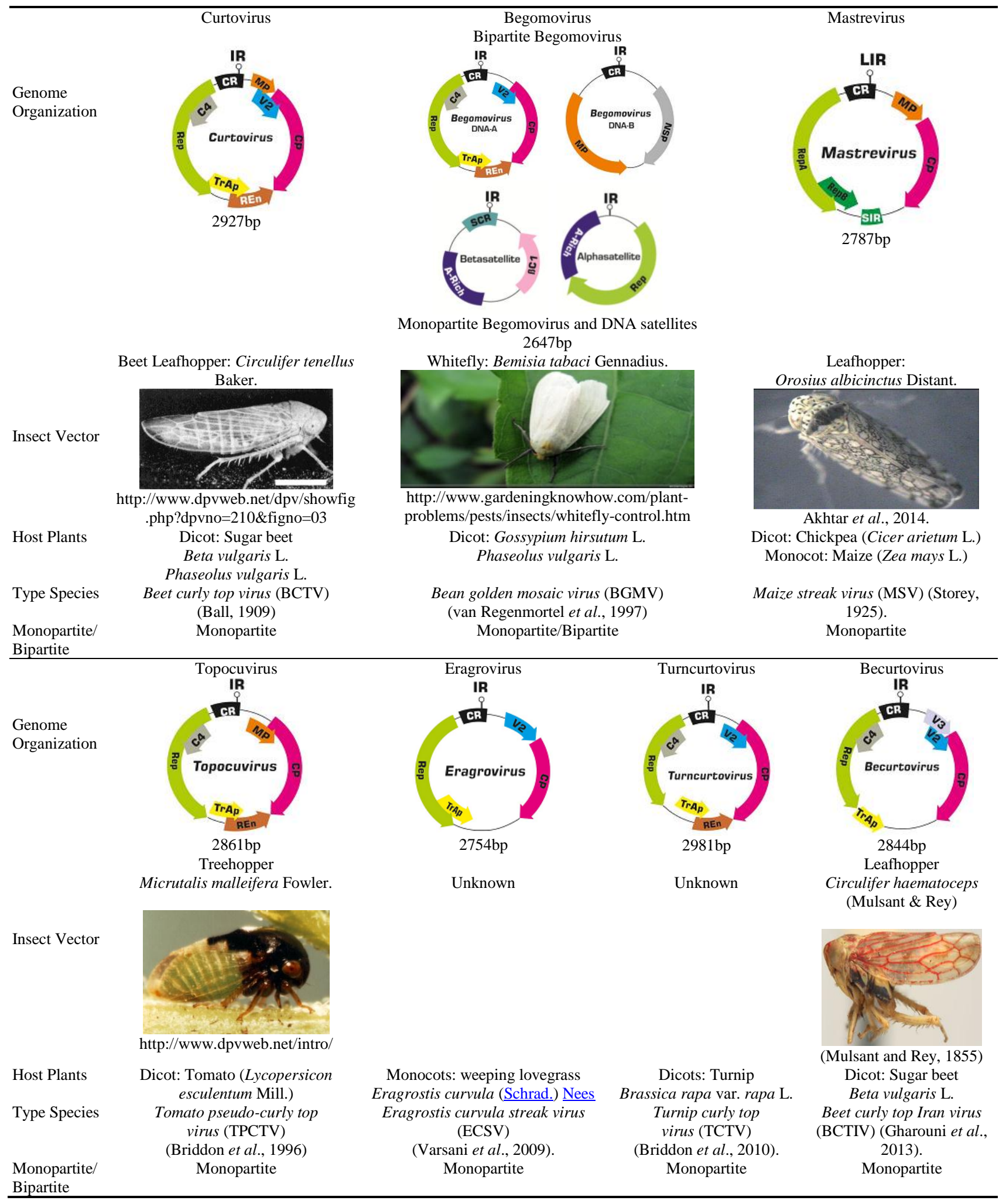

\section{Dicot Infecting Mastreviruses}

Members of the mastrevirus include species, which infect monocotyledonous (monocot) but it has shifted its mood from monocot to dicotyledonous (dicot) plants. The change in the behaviour of viruses of this genus has made them 
worthwhile for study. Mastreviruses, for example Maize streak virus (MSV), and Panicum streak virus (PSV) has been recorded to infect the monocotyledonous plant (Varsani et al., 2009). Whilst dicots infecting mastrevirus viz. Tobacco yellow dwarf virus (TbYDV) from Australia and Chickpea chlorotic dwarf virus (CpCDV) from northern Africa and the Indian subcontinent were being isolated from dicots i.e., tobacco and chickpea respectively (Morris et al., 1992; Horn et al., 1993). Albeit Bean yellow dwarf virus (BeYDV) (Liu et al., 1997a) (infect dicotyledonous plants) presence has been recorded in both Pakistan and South Africa (Halley-Scott et al., 2007). However, Thomas et al. (2010) reported Chickpea chlorosis virus (CpCV-A, CpCVB) and Chickpea redleaf virus (CpRLV) from Australia. Previously, CpCDV has been noted down to attack the legumes but with lapse of time, they expand their host range and infected other dicot families as well, like pepper (in India and Oman) and tomato (Byun et al., 2014; Akhtar et al., 2014; Zia et al., 2015). Now CpCDV not only infect legumes but also the species of other important families like Solanaceae, Asteraceae, Malvaceae and Cucurbitaceae, have economic implications to Asia and the Arabian Peninsula. Likewise cotton (Gossypium L.) being important member of family malvaceae has always played an important role in lifting up the economy of any country including Pakistan (fourth largest cotton producing country). Yet for many members of family Malvaceae the CLCuD reported as a serious disorder in Pakistan and first report was recorded from Tiba Sultanpur near Multan in 1967 (Hussain and Ali, 1975). Unfortunately, CLCuD was ignored until it became a giant disaster for cotton crop in 1987 and turned into serious threat to most of the cotton producing areas of Pakistan such as Sahiwal, Multan, Khanewal, Vehari and Bahawalpur till 1990s (Mansoor et al., 2003).

\section{Mastrevirus Host Range}

Number of plant scientists has reported natural hosts of dicotyledonous plant infecting mastreviruses in the field for example for (i) chickpea: [(Cicer arietinum L.) Horn et al., 1993; Kumari et al., 2004; Nahid et al., 2008; Mumtaz et al., 2011; Kraberger et al., 2013] (ii) lentil: [(Lens culinaris Medik) Nahid et al., 2008; Kraberger et al., 2013] (iii) faba bean: [(Vicia faba L.) Makkouk et al., 2003b; Kraberger et al., 2013] (iv) field pea: [(Pisum sativum L.) Kraberger et al., 2013] (v) french bean: [(Phaseolus vulgaris L.) Liu et al., 1997a; Ali et al., 2004] (vi) sugar beet: [(Beta vulgaris L.) Farzadfar et al., 2008] (vii) pepper: [(Capsicum annum L.) Akhtar et al., 2014; Byun et al., 2014] (viii) cotton: [(Gossypium sp. L.) Manzoor et al., 2014] (ix) squash: [(Cucurbita pepo L.) Fahmy et al., 2015] and for (x) tomato: [(Lycopersicon esculantum L.) Zia et al., 2015]. Additionally many researchers also claimed that weeds like 'Sesbania bispinosa Jacq., 'Rapistrum rugosum L'. and 'Xanthium strumarium L.' are favorite hosts of mastrevirus
(Nahid et al., 2008; Schwinghamer et al., 2010; Mubin et al., 2012).

\section{Reports of Coinfection of Mastrevirus with Begomovirus}

Following research reports revealed that coinfection of viruses belonging to two different genera e.g. mastrevirus and begomovirus occurs very rarely and due to extreme genetic changes, intergenic recombinations are not viable and not as fit as their parents. The prerequisite of coinfection between begomovirus-dicot infecting mastrevirus intergenic recombination was shown first time by Mubin et al. (2012) in a weed (Xanthium strumarium L.: non-host of CpCDV) in Pakistan. This first report about recognition of cooccurrence of a defective mastrevirus was with speculation that they lack coat protein $\mathrm{CP}$ gene and depend on begomovirus for various activities (like encapsidation, cell to cell as well as plant to plant movement). The second evidence of coinfection between 'Cotton leaf curl burewala virus' (CLCuBuV), a begomovirus with dicot infecting mastrevirus; 'Chickpea chlorotic dwarf virus' (CpCDV) was reported by Manzoor et al. (2014) in cotton (non-host of mastrevirus). Recently a new study about begomovirusdicot infecting mastrevirus co-infection in squash plants (non-host species of dicot infecting mastrevirus) has been reported by Fahmy et al. (2015) for full length complete genome of the CpCDV infected squash plants by studying its putative recombination events along with its phylogenetic analysis and molecular characterization. Such reports of co-occurrence of viruses put heavy pressure on recombination events between two different genera of same family but have been transmitted by dissimilar vectors. Begomoviruses are transmitted by whiteflies whereas CpCDV are transmitted by leafhopper Orosius albicinctus Distant (Akhtar et al., 2011). Study of whiteflies and leaf hoppers for the presence of CpCDV isolates in their body will be good contribution. It may provide comprehensive information to perform some forced recombination experiments with a mastrevirus like 'Maize streak virus' (Schnippenkoetter et al., 2001; Martin and Rybicki, 2002).

Very few experiments have been performed so far to study the co-infection of a begomovirus together with a mastrevirus, infecting the same host plant. Hence to explore this aforementioned aspect we designed the study to replace coat protein $(\mathrm{CP})$ gene of $\mathrm{CpCDV}$ (Genus: Mastrevirus, Family: Geminiviridae) with the $\mathrm{CP}$ gene of (CLCuBuV) (Genus: Begomovirus, Family: Geminiviridae). It is hypothesized that the $B$. tabaci might be able to acquire and transmit our chimeric 'MastreBegomo' confirming the observation that coat protein play an integral role in viral transmission by its specific vector. It is therefore suggested that co-evolution of both the genera may open new horizons in understanding the complexity of CLCuD and then to chalk out strategies to counter this emerging threat in Pakistan. 
Functions Associated with Mastrevirus Coat Protein/ Int. J. Agric. Biol., Vol. 19, No. 1, 2017

Table 2: Comparison of Protein functions between Mastrevirus and Begomovirus.

\begin{tabular}{|c|c|c|c|c|}
\hline Geminivirus Genus & Orientation & Gene & Protein & Function \\
\hline \multirow[t]{4}{*}{$\begin{array}{l}\text { Mastrevirus (Monopartite) } \\
\text { Maize streak virus }\end{array}$} & Virion strand & V1 & Movement Protein (MP) & $\begin{array}{l}\text { Cell-to-cell movement in plant (Wright et al., 1997; van } \\
\text { Regenmortel et al., 2000). }\end{array}$ \\
\hline & & $\mathrm{V} 2$ & Coat Protein $(\mathrm{CP})$ & $\begin{array}{l}\text { Systemic infection, encapsidation and insect transmission. } \\
\text { This is the only structural protein that determines both cell-to- } \\
\text { cell movement and vector specificity in plants (Mullineaux et } \\
\text { al., 1984; Boulton et al., 1993). }\end{array}$ \\
\hline & Complementary strand & $\mathrm{C} 1$ & $\begin{array}{l}\text { Replication associated } \\
\text { protein A (RepA) }\end{array}$ & $\begin{array}{l}\text { Transactivation of late genes i.e., virion sense genes along } \\
\text { with establishing a cellular environment conducive for } \\
\text { replication of virus (Hanley-Bowdoin et al., 1999; Boulton et } \\
\text { al., 1993). }\end{array}$ \\
\hline & & $\mathrm{C} 2$ & $\begin{array}{l}\text { Replication associated } \\
\text { protein B (RepB) }\end{array}$ & $\begin{array}{l}\text { Translated from alternatively spliced sense transcripts, } \\
\text { required for replication, initiate and terminate rolling circle } \\
\text { DNA replication and interfere the cell cycle (McGivern, } \\
\text { 2002). }\end{array}$ \\
\hline $\begin{array}{l}\text { Begomovirus } \\
\text { (Bipartite/monopartite.) }\end{array}$ & Virion strand & AV1 & Coat Protein $(\mathrm{CP})$ & $\begin{array}{l}\text { Requisite for transmission of insect as well as mobility in } \\
\text { plant (Rojas et al., 2001) required for stability of genome, } \\
\text { infectivity, transmission by insect vectors and systemic spread } \\
\text { (Lazarowitz, 1992) need for accumulation of ssDNA (Qin et } \\
\text { al., 1998), determinant of the specificity of insect vector } \\
\text { (Briddon et al., 1990). }\end{array}$ \\
\hline $\begin{array}{l}\text { Bipartite: Cotton chlorotic } \\
\text { spot virus (CCSV) de } \\
\text { Almeida } \text { et al., 2013. } \\
\text { Monopartite: Tomato yellow } \\
\text { leaf curl virus (TYLCV) }\end{array}$ & & AV2 & Precoat Protein & $\begin{array}{l}\text { Only confined to old world begomoviruses and involved in } \\
\text { movement of bipartite geminiviruses localized around the } \\
\text { nucleus and at the cell periphery and co-localized with the } \\
\text { endoplasmic reticulum (Padidam et al., 1996), virus } \\
\text { movement in planta (Rojas et al., 2001). }\end{array}$ \\
\hline
\end{tabular}

Complementary strand

$\begin{array}{llll}\text { Virion strand } & \text { BC1 } & \begin{array}{l}\text { Nuclear shuttle protein } \\ \text { (NSP) }\end{array} & \begin{array}{l}\text { Need to alter the structure of plasmodesmata by accelerating } \\ \text { the movement of virus inside host (Pascal } \text { et al., 1993) and } \\ \text { essential in determination of symptom severity due to crucial } \\ \text { role of BC1 gene (Duan } \text { et al., 1997). }\end{array} \\ \begin{array}{l}\text { Complementary } \\ \text { strand }\end{array} \text { DNA-B BV1 Movement protein (MP) } \begin{array}{l}\text { Confined only in nucleus of the host cell and require for } \\ \text { binding to ssDNA, thus transporting it to cytoplasm (Pascal } e t \\ \text { al., 1994). }\end{array}\end{array}$

$\begin{array}{llll}\text { Virion strand } & \text { BC1 } & \begin{array}{l}\text { Nuclear shuttle protein } \\ \text { (NSP) }\end{array} & \begin{array}{l}\text { Need to alter the structure of plasmodesmata by accelerating } \\ \text { the movement of virus inside host (Pascal } \text { et al., 1993) and } \\ \text { essential in determination of symptom severity due to crucial } \\ \text { role of BC1 gene (Duan } \text { et al., 1997). }\end{array} \\ \begin{array}{l}\text { Complementary } \\ \text { strand }\end{array} \text { DNA-B BV1 Movement protein (MP) } \begin{array}{l}\text { Confined only in nucleus of the host cell and require for } \\ \text { binding to ssDNA, thus transporting it to cytoplasm (Pascal } e t \\ \text { al., 1994). }\end{array}\end{array}$

$\begin{array}{llll}\text { Virion strand } & \text { BC1 } & \begin{array}{l}\text { Nuclear shuttle protein } \\ \text { (NSP) }\end{array} & \begin{array}{l}\text { Need to alter the structure of plasmodesmata by accelerating } \\ \text { the movement of virus inside host (Pascal } \text { et al., 1993) and } \\ \text { essential in determination of symptom severity due to crucial } \\ \text { role of BC1 gene (Duan } \text { et al., 1997). }\end{array} \\ \begin{array}{l}\text { Complementary } \\ \text { strand }\end{array} \text { DNA-B BV1 Movement protein (MP) } \begin{array}{l}\text { Confined only in nucleus of the host cell and require for } \\ \text { binding to ssDNA, thus transporting it to cytoplasm (Pascal } e t \\ \text { al., 1994). }\end{array}\end{array}$

AC1 Replication associated Need for replication of viral DNA particles that is the rolling protein (Rep) $\quad$ circle replication initiator protein (Hanley-Bowdoin et al., 2004).

AC2 Transcription associated Suppressor of post-transcriptional gene silencing (PTGS; protein (TrAp) Yang et al., 2007). controls viral induced hypersensitive cell death (Hussain et al., 2007; Mubin et al., 2010),

DNA-A AC3 Replication enhancer Initiate an environment helpful for replication of virus.

AC4 Multifunctional protein Govern the pathogenicity, involved in movement of viral particles, overcoming host defenses as well as suppressor of PTGS (Gopal et al., 2007; Saeed et al., 2008; Vanitharani et al., 2004; Nawaz-ur-Rehman et al., 2010).

$\mathrm{AC} 1, \mathrm{AC} 2, \mathrm{AC} 3$ and $\mathrm{AC} 4$ in bipartite and $\mathrm{C} 1, \mathrm{C} 2, \mathrm{C} 3$ and $\mathrm{C} 4$ in monopartite geminiviruses

\section{Role of Coat Protein in Mastrevirus}

Nucleus of the host plant has been reported as main place for the replication of the geminiviruses during which viral DNA particles move across the cell boundaries copulated with nuclear shuttling eventuate in infection of plant (Goodman, 1981; Davies et al., 1987). In mastreviruses, MSV encode only one MP (PV1) in addition to the CP, requisite of maize infection (Boulton et al., 1993, 1989; Lazarowitz et al., 1989). Contrarily in bipartite geminiviruses, three genes are involved in movement of virus i.e., BR1, BL1 and CP (Jeffrey et al., 1996). The CP of the genus Begomoviruses has one or more common antigenic epitopes signifying them as determinants of vector specificity indicating key role of the CP during transmission of viruses (Roberts et al., 1984; Briddon et al., 1990; Hofer et al., 1997). But transmission of viral particles could be enhanced due to relevant pathogens or parasites which may have ability to induce changes in behavior of host or its vector. As vectors are mobile and show their preferences on infection of host plant hence such effects mainly constraint to vectors. Nevertheless, pathogen spread also depend on different modes viz. mode of acquisition is promoted if noninfective vector has inclination toward infected plants in contrast to transmission where infective vector has preference for non-infected hosts (Ingwell et al., 2012).

The potential role of geminivirus coat protein in determining infectivity (Briddon et al., 1989) and vector specificity in the transmission of geminiviruses was first demonstrated by Briddon et al. (1990). Using gene 
replacement (by using restriction enzymes) Chimera was construct between 'African Cassava Mosaic Virus' [(ACMV) whitefly transmitted Begomovirus] and 'Beat curly top virus' [(BCTV; leafhopper transmitted Curtovirus] where CP gene (AV1) of ACMV was excised by using restriction enzymes and replaced by V2 of BCTV. Successful transmission of both BCTV and chimeric virus was recorded via BCTV leafhopper vector [Circulifer tenellus (Baker)], whereas ACMV failed indicating that chimeric ACMV altered its insect specificity from whiteflies to leafhoppers. Therefore, it has been suggested that coat protein is an essential component for transmission and in identifying specificity of insect.

Further, Hofer et al. (1997) conducted an experiment by inserting $\mathrm{CP}$ gene of insect transmissible 'Sida golden mosaic virus' (SiGMV-Co) to non-transmissible isolate of 'Abutilon mosaic virus' (AbMV) that lacked specific region of coat protein by using specific primers designed in opposite orientation by PCR (polymerase chain reaction) amplification. So, B. tabaci successfully transmitted and acquired this resultant chimera to various host plants. Whereas research reports of Liu et al. (1998) and Azzam et al. (1994) was also supported the aforementioned report where they opined that geminiviruses capsids mutants are not acquired by whiteflies. Experiments of Azzam et al. (1994) clearly depict the role of CP of 'Bean golden mosaic virus' (BGMV) in systemic infection and vector transmission (whitefly). They produced three mutants by introducing two deletions and a restriction fragment inversion, in coat protein gene of BGMV. All the three mutants were non transmissible by whiteflies, non-sap transmissible and showed systemic infection by particle gun method when co-inoculated with DNA-B onto Phaseolus vulgaris $\mathrm{L}$. In mutants, ssDNA accumulation was reduced to 25 to 50 fold in DNA-A and 3 to 10 fold in DNA-B.

Mastrevirus coat protein plays an important role for the infection of host plant but little is known about its function. It has been suggested that $\mathrm{N}$-terminus is vital for nuclear accumulation of CP (Liu et al., 1997b, 1999) and 13 amino acids of C-terminus is necessary for encapsidation and accumulation of ssDNA (Boulton et al., 1989). Yet it has been also explored that $\mathrm{CP}$ of 'Maize streak virus' (MSV) along with most of other cereal-infecting mastreviruses posses a conserved motif of 180-182 amino acids i.e., proline-cysteine-lysine. Though, in previous studies role of lysine was reported as dendro-toxins or inhibitors of Kunitz protease (Dufton, 1985). Ultimately site directed mutagenesis in MSV was performed between lysine and valine in the $\mathrm{CP}$ region which was recorded as mutation of amino acid 182 and has been reported to affect the virion formation due to the absence of systemic infection. However, it does not affect the replication of ssDNA and/or dsDNA and other functions e.g., MP-CP interaction, nuclear accumulation and cell to cell movement (Liu et al., 2001). Infectivity of MSV has also been abolished due to mutation or deletion of/in $\mathrm{CP}$ gene of maize lead to non accumulation of ssDNA particles in protoplast (Boulton et al., 1989, 1993).

Thereupon, Liu et al. (1997b) assessed the dual role of $\mathrm{CP}$ both in encapsidation as well as in transportation of ss and/or ds DNA. By contrast to CP of begomoviruses it was shown that $\mathrm{CP}$ of masriveruses is essential for systemic infection. Howbeit requirements for inter- and- intracellular movement of MSV is in accordance to begomoviruses, consequently even if there is deficiency of DNA B-encoded proteins, two proteins viz. CP and MP might have operative role similar to $\mathrm{BV} 1$ and $\mathrm{BC} 1$ (movement proteins) of begomoviruses yet their structure and manner of function might be dissimilar (Liu et al., 1999). Nevertheless, a specific CP region (i.e., 1-104 amino acids) of MSV is mapped as DNA binding domain but any disruption or alteration of this area and subsequently deletion of $20 \mathrm{~N}$ terminal amino acids that have an effect on refolding of protein so their DNA binding ability diminishes.

As recommended for $\mathrm{BR} 1$ of $\mathrm{SqLCV}$, this coat protein region may bind viral ssDNA in the form of nucleoprotein which help both for cell to cell movement and in nuclear shuttling (Pascal et al., 1994; Sanderfoot et al., 1996). It is likely that CP binding function is helpful for encapsidation of viral (ss) DNA. Probably, CP complexed with dsDNA or ssDNA will interact with movement protein (MP) to carry out inter- and intra-cellular movement just like BL1 and BR1 of SqLCV (Pascal et al., 1994). Later on a comparative study was performed by Benfey et al. (1996) in transgenic rice plants (Oryza sativa L.) to study the mastrevirus coat protein promoter activity with that plants transformed with the gus gene; downstream of the 'Cauliflower mosaic virus' (CaMV) 35S promoter. A cp-gus reporter gene replacement construct was made in order to study the tissue specificity and strength of MSV CP promoter region. The construct was theorized as MSV CP 'extended promoter' comprised of MSV (i) LIR and (ii) SIR, (iii) sequence of MP gene and (iv) replication associated regions of the genes. Though activation of MSV CP promoter was figured out inside the regenerating callus cells but for vascular tissues of regenerated plants such expression patterns were confined only to vascular tissues of above and below ground parts like stem, leaf, and flower and root. However, in phloemassociated tissues of the vegetative organs highest expression were assessed but no expression was observed in seedling roots (tip and elongation part). While working on transgenic rice Mazithulela et al. (2000) juxtapose the characteristics of MSV CP 'extended promoter' with that of CaMV $35 \mathrm{~S}$ promoter to evaluate their utilization for tissuespecific expression.

For the host plants, two important stimuli viz. gustatory and olfactory stimuli are produced for which sensory receptors on the rostral apex of order Hemiptera were considered useful (Rani and Madhavendra, 1995, 2005) whilst chemosensilla is mainly found on the mouthparts and antennae. Members of order Hemiptera also enjoy the existence of contact chemoreceptive 'sensilla on 
the labial tip' which give facts about nature of leaf surface to insect when it tap it on the leaf of host plant (Backus et al., 1982). Previously chemosensory functions of such 'apical labial sensilla' have also been listed by Backus and McLean (1983) and Walker and Gordh (1989) in leafhoppers and whiteflies respectively. It is also insinuated that 'apical labial sensilla' have multiple role like in host selection, discriminate between host and non-host tissues and likely function in either chemo and/or mechano-sensory or both (Zhao et al., 2010). Further research, however, is need of the hour to understand the more detailed and fine structure of the labial sensilla of leafhoppers.

\section{Conclusion}

In a nutshell it can be concluded that replacement of coat protein gene of $\mathrm{CpCDV}$ with $\mathrm{CLCuBuV}$ may help to broaden our understanding about the range and distribution of mastreviruses across Pakistan and will provide the necessary information regarding their control. Keeping in view the available information regarding mastreviruses, we have adopted advance molecular techniques, which aimed at to find out the possibility of co-infection of mastreviruses with begomoviruses. Hence may provide scientific community in depth knowledge about the diversity and prevalence of mastreviruses globally, not only in monocots but also in dicots together with begomoviruses. Whereas, it will further open avenues for researchers to find out the potential factors, which made the mastreviruses to evolve from monocotyledonous plants to dicotyledonous and their ability to cause infection in non-host plants, thus expanding its host range with the passage of time.

\section{References}

Ahmad, M., M. Rafiq, M.I. Arif and A.H. Sayyed, 2011. Toxicity of some commonly used insecticides against Coccinella undecimpunctata (Coleoptera: Coccinellidae). Pak. J. Zool., 43: 1161-1165

Akhtar, K.P., M. Ahmad, T.M. Shah and B.M. Atta, 2011. Transmission of chickpea chlorotic dwarf virus in chickpea by the leafhopper Orosius albicinctus (Distant) in Pakistan-short communication. Plant Protect. Sci., 47: 1-4

Akhtar, S., A.J. Khan and R.W. Briddon, 2014. A distinct strain of Chickpea chlorotic dwarf virus infecting pepper in Oman. Plant Dis., 98: 286

Ali, M.A., S.G. Kumari., K.H. Makkouk and M.M. Hassan, 2004. Chickpea chlorotic dwarf virus, CpCDV naturally infects Phaseolus bean and other wild species in the Gezira region of Sudan. A.J. Plant Prot., 22: 96

Amin, I., S. Mansoor, L. Amrao, M. Hussain, S. Irum, Y. Zafar, S.E. Bull and R.W. Briddon, 2006. Mobilisation into cotton and spread of a recombinant cotton leaf curl disease satellite. Arch. Virol., 151: 2055-2065

Azzam, O., J. Frazer, D. de la Rosa, J.S. Beaver, P. Ahlquist and D.P. Maxwell, 1994. Whitefly transmission and efficient ssDNA accumulation of bean golden mosaic geminivirus require functional coat protein. Virology, 204: 289-296

Backus, E.A. and D.L. McLean, 1982. The sensory systems and feeding behavior of leafhoppers. I. The aster leafhopper, Macrosteles fascifrons Stal. (Homoptera, Cicadellidae). J. Morphol., 172: 361-379
Backus, E.A. and D.L. McLean, 1983. The sensory systems and feeding behavior of leafhoppers. II. A comparison of the sensillar morphologies of several species (Homoptera: Cicadellidae). $J$. Morphol., 176: 3-14

Bailey, M.A., 1934. Leaf curl disease of cotton in the Sudan. Empire Cotton Gr. Rev., 11: 280-288

Ball, E.D., 1909. The Leafhoppers of the Sugar Beet and Their Relation to the "Curly Leaf" Condition, Vol. 66, p: 33. U.S. Department of Agriculture, Bureau of Entomology

Benfey, P.N., L. Ren and N.H. Chua, 1996. The CaMV 35S enhancer contains at least two domains which can confer different developmental and tissue-specific expression patterns. EMBO J., 8: 2195-2202

Bock, K.R., E.J. Guthrie and R.D. Woods, 1974. Purification of Maize streak virus and its relationship to viruses associated with streak diseases of sugar cane and Panicum maximum. Ann. Appl. Biol., 77: 289-296

Boulton, M.I., 2002. Functions and interactions of mastrevirus gene products. Physiol. Mol. Plant Pathol., 60: 243-255

Boulton, M.I., C.K. Pallaghy, M. Chatani, S. MacFarlane and J.W. Davies, 1993. Replication of Maize streak virus mutants in maize protoplasts: evidence for a movement protein. Virology., 192: 85-93

Boulton, M.I., H. Steinkellner, J. Donson, P.G. Markham, D.I. King and J.W. Davies, 1989. Mutational analysis of the virion-sense genes of Maize streak virus. J. Gen. Virol., 70: 2309-2323

Boulton, M.I. and P.G. Markham, 1986. The use of squash blotting to detect plant pathogens in insect vectors In: Developments in Applied Biology". Developments Applications in Virus Testing. 1: 55-69

Briddon, R.W., J. Heydarnejad, F. Khosrowfar, H. Massumi, D.P. Martin and A. Varsani, 2010. Turnip curly top virus, a highly divergent geminivirus infecting turnip in Iran. Virus Res., 152: 169-175

Briddon, R.W. and P.G. Markham, 2001. Cotton leaf curl virus disease. Virus Res., 71: 151-159

Briddon, R.W., I.D. Bedford, J.H. Tsai and P.G. Markham, 1996. Analysis of the nucleotide sequence of the treehopper-transmitted geminivirus, tomato psueudo-curly top virus, suggests a recombinant origin. Virology., 219: 387-394

Briddon, R.W., M.S. Pinner, J. Stanley and P.G. Markham, 1990 Geminivirus coat protein replacement alters insect specificity. Virology, 177: 85-94

Briddon, R.W., J. Walts, P.G. Markham and J. Stanley, 1989. The coat protein of Beet curly top virus is essential for infectivity. Virology, 172: 628-633

Byun, H.S., E.J. Kil., S. Kim and H. Hwang, 2014. First Report of Chickpea chlorotic dwarf virus infecting hot pepper in India. Plant Dis., 98: 1590

Davies, J.W., J. Stanley, J. Donson, P.M. Mullineaux and M.I. Boulton, 1987. Structure and replication of geminivirus genomes. J. Cell. Sci. Suppl., 7: 95-107

De Almeida, M.M.S., S. Jain, P.A.V. Barroso, L.V. Hoffmann, M.G. de Lucena, R.D.O. Resende and A.K. Inoue-Nagata, 2013. Complete sequence of a new bipartite begomovirus infecting cotton plants in Brazil. Genome Announc., 1: 00661-00613

Duan, Y.P., C.A. Powell, S.E. Webb, D.E. Purcifull and E. Hiebert, 1997 Geminivirus resistance in transgenic tobacco expressing mutated BC1 protein. Mol. Plant-Microbe Interact., 10: 617-623

Dufton, M.J., 1985. Proteinase inhibitors and dendrotoxins. Sequenceclassification, structural prediction and structure/activity Eur. J. Biochem., 153: 47-54

El-Muadhidi, M.A., K.M. Makkouk, S.G. Kumari, M. Jerjess, S.S. Murad, R.R. Mustafa and F. Tarik, 2001. Survey for legume and cereal viruses in Iraq. Phytopathol. Mediterr., 40: 224-233

Fahmy, I.F., O. Taha and A.N. El-Ashry, 2015. First genome analysis and molecular characterization of Chickpea chlorotic dwarf virus Egyptian isolate infecting squash. Virus Dis., 26: 33-34

Farooq, A., J. Farooq, A. Mahmood, A. Shakeel, A. Rehman, A. Batool, M. Riaz, M.T.H. Shahid, S. Mehboob, 2011. An overview of cotton leaf curl virus disease (CLCuD) a serious threat to cotton productivity. Aust. J. Crop Sci., 5: 1823-1831 
Farquarson, C.O., 1912. A Report of the Mycologist, p: 196. Agriculture Department, Nigeria

Farzadfar, S., R. Pourrahim, A.R. Golnaraghi, N. Shahraeen and K.M Makkouk, 2002. First report of sugar beet and bean as natural hosts of Chickpea chlorotic dwarf virus in Iran. Plant Pathol., 51: 795-795

Farzadfar, S.H., R. Pourrahim, A.R. Golnaraghi and A. Ahoonmanesh, 2008. PCR detection and partial molecular characterization of Chickpea chlorotic dwarf virus in naturally infected sugar beet plants in Iran. J. Plant Pathol., 90: 247-251

Gharouni Kardani, S., J. Heydarnejad, M. Zakiaghl, M. Mehrvar, S. Kraberger and A. Varsani, 2013. Diversity of beet curly top Iran virus isolated from different hosts in Iran. Virus Genes., 46: 571-575

Goodman, R.M., 1981. Geminiviruses. In Handbook of Plant Virus Infection \& Comparative Diagnosis, pp: 879-910. Kustak, E. (ed.). New York: Elsevier, North Holland Biomedical Press

Gopal, P., P. Kumar, B. Sinilal, J. Jose, A. Kasin Yadunandam and R. Usha, 2007. Differential roles of $\mathrm{C} 4$ and ${ }^{`} \mathrm{C} 1$ in mediating suppression of post-transcriptional gene silencing: evidence for transactivation by the $\mathrm{C} 2$ of Bhendi yellow vein mosaic virus, a monopartite begomovirus. Virus Res., 123: 9-18

Halley-Stott, R.P., F. Tanzer, D.P. Martin and E.P. Rybicki, 2007. The complete nucleotide sequence of a mild strain of Bean yellow dwarf virus. Arch. Virol., 152: 1237-1240

Halley-Stott, R.P., F. Tanzer, D.P. Martin and E.P. Rybicki, 2007. The complete nucleotide sequence of a mild strain of Bean yellow dwarf virus. Arch. Virol., 152: 1237-1240

Hanley-Bowdoin, 1., S.B. Settlage and D. Robertson, 2004. Reprogramming plant gene expression: a prerequisite to geminivirus DNA replication. Mol. Plant Pathol., 5: 149-156

Hanley-Bowdoin, L., S.B. Settlage, B.M. Orozco, S. Nagar and D. Robertson, 1999. Geminviruses: models for plant DNA replication, transcription, and cell cycle regulation. Crit. Rev. Plant Sci., 18: 71-106

Harrison, B.D., M.M. Swanson and D. Fargette, 2002. Begomovirus coat protein: serology, variation and functions. Physiol. Mol. Plant. P., 60: $257-271$

Heyraud-Nitschke, F., S. Schumacher, J. Laufs, S. Schaefer, J. Schell and B. Gronenborn, 1995. Determination of the origin, cleavage and joining domain of geminivirus Rep proteins. Nucleic Acids Res., 23: 910 916

Hofer, P., I.D. Bedford, P.G. Markham, H. Jeske and T. Frischmuth, 1997. Coat protein gene replacement results in whitefly transmission of an insect nontransmissible geminivirus isolate. Virology, 236: 288-295

Horn, N.M., S.V. Reddy, I.M. Roberts and D.V.R. Reddy, 1993. Chickped chlorotic dwarf virus, a new leafhopper-transmitted geminivirus of chickpea in India. Ann. Appl. Biol., 122: 467-479

Horn. N.M., S.V. Reddy, J.F.M. Van den Heuvel and D.V.R. Reddy, 1996. Survey of chickpea (Cicer arietinum L.) for chickpea stunt disease and associated viruses in India and Pakistan. Plant Dis., 80: 286-290

Hussain, M., S. Mansoor, S. Iram, Y. Zafar and R.W. Briddon, 2007. The hypersensitive response to tomato leaf curl New Delhi virus nuclear shuttle protein is inhibited by transcriptional activator protein. MPMI, 20: 1581-1588

Hussain, T. and M. Ali, 1975. A review of cotton diseases of Pakistan. The Pak. Cott., 19: 71-86

Ingwell, L.L., S.D. Eigenbrode and N.A. Bosque-Pe'rez, 2012. Plant viruses alter insect behavior to enhance their spread. Scientific Reports, 2 578

Inouye, T. and T. Osaki, 1980. The first record in the literature of the possible plant virus disease that appeared in Manyoshu, a Japanese classic anthology, as far back as the time of the 8th century. Ann. Phytopathol. Soc. Jpn., 46: 49-50

Jeffrey, J.L., W. Pooma and I.T.D. Petty, 1996. Genetic requirement for the local and systemic movement of tomato golden mosaic virus in infected plants. Virology, 223: 208-218

Jeske, H., 2009. Geminiviruses. In: TT Viruses: The Still Elusive Human Pathogens, pp: 185 TT Viruses 226. Edited by: de Villers, E.M., Zur Hausen and H. Berlin (eds.). Springer Verlag

Jones, G.H. and T.G. Mason, 1926. Studies on two obscure diseases of cotton. Ann. Bot., 160: 759-772
Kheyr-Pour, A., M. Bendahmane, V. Matzeit, G.P. Accotto, S. Crespi and B. Gronenborn, 1991. Tomato yellow leaf curl virus from Sardinia is a whitefly-transmitted monopartite geminivirus. Nucleic Acids Res., 19: 6763-6769

Kraberger, S., G.W. Harkins, S.G. Kumari, J.E. Thomas, M.W Schwinghamer, M. Sharman, D.A. Collings, R.W. Briddon, D.P. Martin and A. Varsani, 2013. Evidence that dicot-infecting mastreviruses are particularly prone to inter-species recombination and have likely been circulating in Australia for longer than in Africa and the Middle East. Virology, 444: 282-291

Kumari, S.G., K.M. Makkouk, N. Attar, W. Ghulam and D.E. Lesemann, 2004. First report of Chickpea chlorotic dwarf virus infecting spring chickpea in Syria. Plant Dis., 88: 424

Lazarowitz, S.G., 1992. Geminiviruses: Genome structure and gene function. Crit. Rev. Plant Sci., 11: 327-349

Lazarowitz, S.G., A.J. Pinder, V.D. Damsteegt and S.G. Rogers, 1989. Maize streak virus genes essential for systemic spread and symptom development. EMBO J., 8: 1023-1032

Levy, A. and T. Tzfira, 2010. Bean dwarf mosaic virus: a model system for the study of viral movement. Mol. Plant Pathol., 11: 451-461

Liu, H., M.I. Boulton and J.W. Davies, 1997b. Maize streak virus coat protein binds single- and double-stranded DNA in vitro. J. Gen. Virol., 78: 1265-1270

Liu, H., M.I. Boulton, C.L. Thomas, D.A.M. Prior, K.J. Oparka and J.W Davies, 1999. Maize streak virus coat protein is karyophyllic and facilitates nuclear transport of viral DNA. Mol. Plant-Microbe Interact., 12: 894-900

Liu, H., A.P. Lucy, J.W. Davies and M.I. Boulton, 2001. A single amino acid change in the coat protein of Maize streak virus abolishes systemic infection, but not interaction with viral DNA or movement protein. Mol. Plant Pathol., 2: 223-228

Liu, L., J.W. Davies and J. Stanley, 1998. Mutational analysis of Bean yellow dwarf virus, a geminivirus of the genus Mastrevirus that is adapted to dicotyledonous plants. J. Gen. Virol., 79: 22652274

Liu, L., T. van Tonder, G. Pietersen, J.W. Davies and J. Stanley, 1997a Molecular characterization of a subgroup I geminivirus from a legume in South Africa. J. Gen. Virol., 78: 2113-2117

Makkouk, K.M., G. Dafalla, M. Hussein and S.G. Kumari, 1995. The natural occurrence of Chickpea chlorotic dwarf geminivirus in chickpea and faba bean in the Sudan. J. Phytopathology., 143: 465466

Makkouk, K.M., H.S. Bahamish, S.G. Kumari and A. Lotf, 1998. Major viruses affecting faba bean (Vicia faba L.) in Yemen. Arab J. Plant Prot., 16: 98-101

Makkouk, K.M., L. Rizkallah, S.G. Kumari, M. Zaki and R. Abul Enein, 2003b. First record of Chickpea chlorotic dwarf virus (CpCDV) affecting faba bean (Vicia faba) crops in Egypt. Plant Pathol., 52: 413

Makkouk, K.M., S.G. Kumari, N. Shahraeen, Y. Fazlali, S. Farzadfar, T. Ghotbi and A.R. Mansouri, 2003a. Identification and seasonal variation of viral diseases of chickpea and lentil in Iran. Zeitschrift furPflanzenkrankheiten und Pflanzenschutz. J. Plant Dis. Protect. 110: $157-169$

Mansoor, S., I. Amin, S. Iram, M. Hussain, Y. Zafar, K.A. Malik and R.W. Briddon, 2003. The breakdown of resistance in cotton to cotton leaf curl disease in Pakistan. New Dis. Rep., 52: 784

Manzoor, M., M. Ilyas, M. Shafiq, M.S. Haider, A.A. Shahid and R.W. Briddon, 2014. A distinct strain of Chickpea chlorotic dwarf virus (genus Mastrevirus, family Geminiviridae) identified in cotton plants affected by leaf curl disease. Arch. Virol., 159: 1217-1221

Martin, D.P. and E.P. Rybicki, 2002. Investigation of Maize streak virus Pathogenicity Determinants Using Chimaeric Genomes. Virology, 300: $180-188$

Mazithulela, G., D. Sudhakar, T. Heckel, L. Mehlo, P. Christou, J.W. Davies and M.I. Boulton, 2000. The Maize streak virus coat protein transcription unit exhibits tissue-specific expression in transgenic rice. Plant Sci., 155: 21-29

McGivern, D., 2002. Functional analysis of the Maize streak virus Replication-associated Protein. Ph.D. Thesis. UEA: Norwich, UK 
Morris, B.A.M., K.A. Richardson, A. Haley, X.C. Zhan and J.E. Thomas, 1992. The nucleotidesequence of theinfectious cloned DNA component of Tobacco yellow dwarf virus reveals features of geminiviruses infecting monocotyledonous plants. Virology, 187: 633-642

Mubin, M., I. Amin, L. Amrao, R.W. Briddon and S. Mansoor, 2010. The hypersensitive response induced by the $\mathrm{V} 2$ protein of a monopartite begomovirus is countered by the $\mathrm{C} 2$ protein. Mol. Plant Pathol., 11: $245-254$

Mubin, M., S. Mansoor and R.W. Briddon, 2012. Mastrevirus sequences in a begomovirus-infected plant. Virus Genes., 44: 536-538

Muhire, B., D.P. Martin, J.K. Brown, J. Navas-Castillo, E. Moriones, M.F. Zerbini, R.F. Rivera-Bustamante, V.G. Malathi, R.W. Briddon and A. Varsani, 2013. A genome-wide pairwise-identity-based proposal for the classification of viruses in the genus Mastrevirus (family Geminiviridae). Arch. Virol., 158: 1411-1424

Mullineaux, P.M., J. Donson, B.A.M. Morris-Krsinich, M.I. Boulton and J.W. Davies, 1984. The nucleotide sequence of Maize streak virus DNA. EMBO J., 3: 3063-3068

Mulsant M.E. and J. Rey, 1855. Descriptions de quelques HémipteresHomoptères nouveaux ou peu connus. Annales de la Société Linnéenne de Lyon. Lyon., 2: 197-249

Mumford, D.L., 1974. Purification of Curly top virus. Phytopathology, 64 136-142

Mumtaz, H., S.G. Kumari, S. Mansoor, D.P. Martin and R.W. Briddon, 2011. Analysis of the sequence of a dicot-infecting mastrevirus (family Geminiviridae) originating from Syria. Virus Genes, 42: 422-428

Nahid, N., I. Amin, S. Mansoor, E.P. Rybicki, E. van der Walt and R.W. Briddon, 2008. Two dicot-infecting mastreviruses (family Geminiviridae) occur in Pakistan. Arch. Virol., 153: 1441-1451

Navot, N., E. Pichersky, M. Zeidan, D. Zamir and H. Czosnek, 1991. Tomato yellow leaf curl virus: a whitefly-transmitted Geminiviruses with a single genomic component. Virology, 185: 151-161

Nawaz-Ul-Rehman, M.S., N. Nahid, S. Mansoor, R.W. Briddon and C.M. Fauquet, 2010. Post-transcriptional gene silencing suppressor activity of two non-pathogenic alphasatellites associated with a begomovirus. Virology, 405: 300-308

Nawaz-ul-Rehman, M.S. and C.M. Fauquet, 2009. Evolution of geminiviruses and their satellites. FEBS Lett., 583: 1825-1832

Padidam, M., R.N. Beachy and C.M. Fauquet, 1996. The role of AV2 ("precoat") and coat protein in viral replication and movement in tomato leaf curl geminivirus. Virology, 224: 390-404

Pascal, E., A.A. Sanderfoot, B.M. Ward, R. Medville, R. Turgeon and S.G. Lazarowitz, 1994. The geminivirus BR1 movement protein binds single-stranded DNA and localizes to the cell nucleus. Plant Cell, 6: 995-1006

Pascal, E., P.E. Goodlove, L.C. Wu and S.G. Lazarowitz, 1993. Transgenic tobacco plants expressing the geminivirus BL1 protein exhibit symptoms of viral disease. Plant Cell., 5: 795-807

Qin, S., B.M. Ward, S.G. Lazarowitz and S.W. Qin, 1998. The bipartite geminivirus coat protein aids BR1 function in viral movement by affecting the accumulation of viral single-stranded DNA. J. Virol., 72: 9247-9256

Rani, P.U. and S.S. Madhavendra, 1995. Morphology and distribution of antennal sense organs and diversity of mouthpart structures in Odontopus nigricornis (Stall) and Nezara viridula L. (Hemiptera) Int. J. Insect Morphol. Embryol., 24: 119-132

Rani, P.U. and S.S. Madhavendra, 2005. External morphology of antennal and rostral sensillae in four hemipteran insects and their possible role in host plant selection. Int. J. Trop. Insect Sci., 25: 198-207

Roberts, I.M., D.J. Robinson and B.D. Harrison, 1984. Serological relationships and genome homologies among geminiviruses. J. Gen. Virol., 65: 1723-1730

Rojas, M.R., H. Jiang, R. Salati, B. Xoconostle-Cazares, M.R. Sudarshana, W.J. Lucas and R.L. Gilbertson, 2001. Functional analysis of proteins involved in movement of the monopartite begomovirus, Tomato yellow leaf curl virus. Virology., 291: 110-125

Ruschhaupt, M., D.P. Martin, F. Lakay, M. Bezuidenhout, E.P. Rybicki, H. Jeske and D.N. Shepherd, 2013. Replication modes of Maize streak virus mutants lacking RepA or the RepA-pRBR interaction motif. Virology., 442: 173-179
Saeed, M., S. Mansoor, M.A. Rezaian, R.W. Briddon and J.W. Randles, 2008. Satellite DNA overrides the pathogenicity phenotype of the C4 gene of Tomato leaf curl virus, but does not compensate for loss of function of the coat protein and V2 genes. Arch. Virol., 153: 13671372

Sanderfoot, A.A., D.J. Ingham and S.G. Lazarowitz, 1996. A viral movement protein as a nuclear shuttle. The geminivirus BR1 movement protein contains domains essential for interaction with BL1 and nuclear localization. Plant Physiol., 110: 23-33

Schalk, H.J., V. Matzeit, B. Schiller, J. Schell and B. Gronenborn, 1989. Wheat dwarf virus, a geminivirus of graminaceous plants needs splicing for replication. EMBO J., 8: 359-364

Schnippenkoetter, W.H., D.P. Martin, J.A. Willment and E.P. Rybicki, 2001. Forced recombination between distinct strains of Maize streak virus. J. Gen. Virol., 82: 3081-3090

Schwinghamer, M.W., J.E. Thomas, M.A. Schilg, J.N. Parry, E.K. Dann, K.J. Moore and S.G. Kumari, 2010. Mastreviruses in chickpea (Cicer arietinum) and other dicotyledonous crops and weeds in Queensland and northern New South Wales, Australia. Australas Plant Pathol., 39: 551-561

Settlage, S.B., R.G. See and L. Hanley-Bowdoin, 2005. Geminivirus C3 protein: replication enhancement and protein interactions. J. Virol., 79: 9885-9895

Singh, K., S. Singh and R.K. Gumber, 1996. Resistance to Mungbean yellow mosaic virus in mungbean. Ind. J. Pulses Res., 9: 90-97

Storey, H.H., 1925. The transmission of streak disease of maize by the leafhopper Balclutha mbila Naude. Ann. Appl. Biol., 12: 422-439

Thomas, J., J. Parry, M. Schwinghamer and E. Dann, 2010. Two novel mastreviruses from chickpea (Cicer arietinum) in Australia. Arch. Virol., 155: 1777-1788

Van Regenmortel, M.H.V., D.H. Bishop, C.M. Fauquet, M.A. Mayo, J. Maniloff and C.H. Calisher, 1997. Guidelines to the demarcation of virus species. Arch. Virol., 142: 1505-1518

Van Regenmortel, M.H.V., M.A. Mayo, C.M. Fauquet and J. Maniloff, 2000. Virus nomenclature: consensus versus chaos. Arch. Virol., 145: 2227-2232

Vanitharani, R., P. Chellappan, J.S. Pita and C.M. Fauquet, 2004 Differential roles of AC2 and AC4 of cassava geminiviruses in mediating synergism and suppression of posttranscriptional gene silencing. J. Virol., 78: 9487-9498

Varsani, A., A.L. Monjane, L. Donaldson, S. Oluwafemi, I. Zinga, K.E. Komba, D. Plakoutene, N. Mandakombo, J. Mboukoulida, S. Semballa, R.W. Briddon, P.G. Markham, J.M. Lett, P. Lefeuvre, E.P. Rybicki and D.P. Martin, 2009. Comparative analysis of Panicum streak virus and Maize streak virus diversity, recombination patterns and phylogeography. Virol. J., 6: 194

Varsani, A., J. Navas-Castillo, E. Moriones, C. Hernández-Zepeda, A. Idris, J.K. Brown, F.M. Zerbini and D.P. Martin, 2014. Establishment of three new genera in the family Geminiviridae: Becurtovirus, Eragrovirus and Turncurtovirus. Arch. Virol., 159: 2193-2203

Walker, G.P. and G. Gordh, 1989. The occurrence of apical labial sensilla in the Aleyrodidae and evidence for a contact chemosensory function. Entomol. Exp. Appl., 51: 215-224

Wright, E.A., T. Heckel, J. Groenendijk, J.W. Davies and M.I. Boulton, 1997. Splicing features in Maize streak virus virion- and complementary-sense gene expression. Plant J., 12: 1285-1297

Yang, X.J., S. Baliji, R.C. Buchmann, H. Wang, J.A. Lindbo, G. Sunter and D.M. Bisaro, 2007. Functional modulation of the geminivirus AL2 transcription factor and silencing suppressor by self-interaction. $J$. Virol., 81: 11972-11981

Zhao, L., W. Dai, C. Zhang and Y. Zhang, 2010. Morphological characterization of the mouthparts of the vector leafhopper Psammotettix striatus (L.) (Hemiptera: Cicadellidae). Micron, 41: 754-759

Zia-Ur-Rehman, M., U. Hameed, H.W. Herrmann, M.J. Iqbal, M.S. Haider and J.K. Brown, 2015. First report of Chickpea chlorotic dwarf virus infecting tomato crops in Pakistan. Plant Dis., 99: 1287

(Received 17 September 2016; Accepted 08 November 2016) 